\title{
Material
}

\section{Pericentric Inversion in Homologues of Chromosome 9}

\author{
T. SUDHA* and S. JAYAM \\ Genetic Laboratory, Down's Research Society (India), Vijaya Hospital, \\ 180 NSK Salai, Vadapalani, Madras 600026, India
}

Key Words chromosome 9, pericentric inversion, homologues, consanguinity

\section{Introduction}

Pericentric inversion in one of the chromosomes of 9 is a commonly observed structural variation in the human population and this is transmitted as a dominant character, since it is not known to result in deleterious consequences (De La Chapelle et al., 1974). This anomaly is also observed in association with congenital abnormalities and reproductive loss (Boue et al., 1975; Tibiletti et al., 1981; Sudha and Gopinath, 1991).

An instance of pericentric inversion in both the homologues of chromosome 9, was observed in a female child with labial adhesion. In literature, five individuals have been reported with such condition, having different phenotypes (Wahrman et al., 1972; De La Chapelle et al., 1974; Vine et al., 1976; Sakagami et al., 1988).

\section{Case history}

The female child (11/2 years) was referred for chromosomal analysis due to the fusion of labia minora. The line of adhesion was firm and thick. Labia majora was well formed and urethra and clitoris were present. The ultra-sonographic report revealed the following details: uterus $2.6 \times 0.7 \mathrm{~cm}$; right ovary $1.2 \times 0.6 \mathrm{~cm}$; left ovary $1.0 \times 0.6 \mathrm{~cm}$; giving an impression of normal uterus and ovaries. The child was active and intelligent.

Proband was the only child of a consanguineously married couples (first cousins, once removed-Fig. 1). Instances of deaf mutes, blood cancer and fetal loss were reported in some of the family members.

Received January 21, 1993; Revised version accepted May 13, 1993.

*Present address: National Institute of Genetics, Mishima, Shizuoka 411, Japan. 


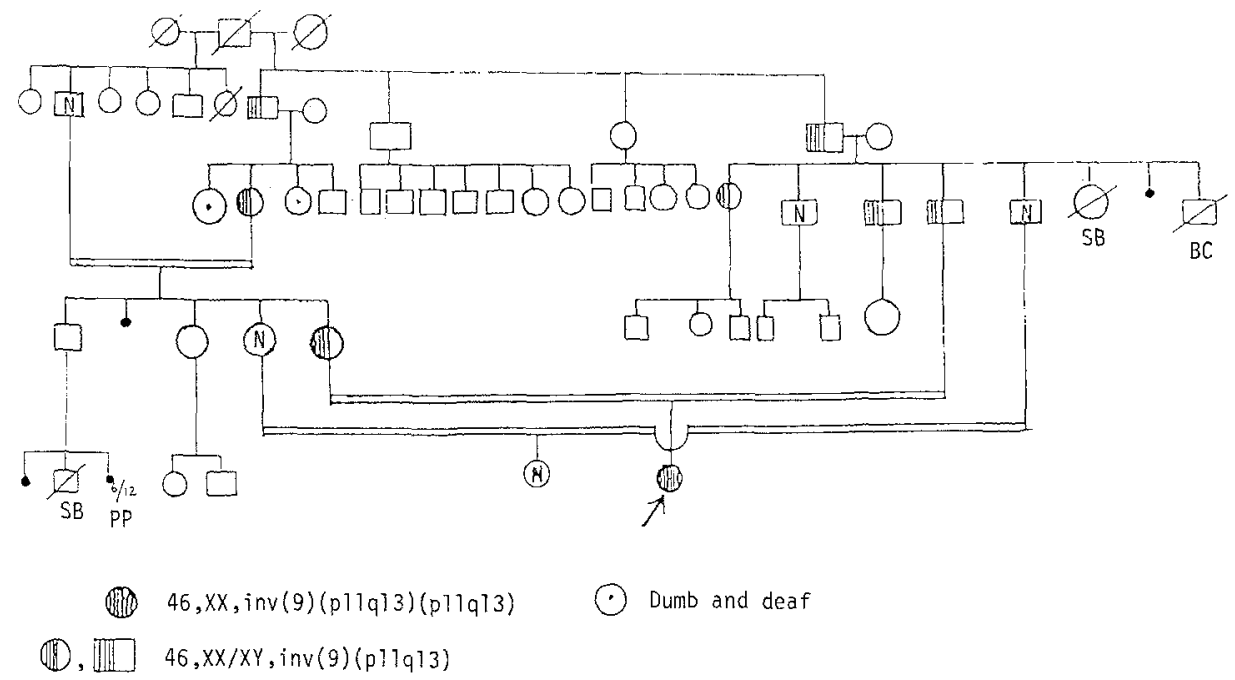

Fig. 1. Pedigree showing the transmission of pericentric inversion of chromosome 9 leading to inversion in homologues.

\section{Cytogenetic analysis}

Leucocyte cultures were established. Cytogenetic analysis of the G-banded metaphases of the proband, revealed inversion 9 in the homologues and the karyotype was $46, \mathrm{XX}$, inv(9)(p1lq13),(p1lq13). C-banding was carried out which confirmed the pericentric inversion. This inversion was found to be inherited from her parents, who had inv(9) in heterozygous condition. Further, cytogenetic investigations of ten other family members showed the anomaly in five of them, with no phenotypic abnormalities (Fig. 1), and also revealed its common origin.

Except in the patient described by Sakagami et al. (1988), the homozygous condition of inv(9) was a result of consanguineous marriages in the parents. Mental and growth retardation and other clinical abnormalities were observed by $\mathrm{De} \mathrm{La}$ Chapelle et al. (1974) and Sakagami et al. (1988) when this variation was recorded in homozygous condition. However, no such phenotypic anomalies were seen in the present case and also in the other reports by Wahrman et al. (1972) and Vine et al. (1976).

It can be considered that, the inversion in chromosome 9 as a casual co-existence with different clinical abnormalities and there seemed to be no definite correlation with homozygous inv(9) condition and phenotypic anomalies. However, members of this particular family may be useful as a source of DNA anaiysis of chromosome 9, homozygosity.

Acknowledgements The authors acknowledge the Down's Research Society (India) for permitting this work to be published and Rotary club of Madras Southwest, for their encouragement. They thank Prof. P.M. Gopinath and Prof. Takeshi Seno for their help. 


\section{References}

Boue J, Taillemite JL, Hazael-Massieux P, Leonard C, Boue A (1975): Association of pericentric inversion of chromosome 9 and reproductive failure in ten unrelated families. Hum Genet 30: $217-224$

De La Chapelle A, Schroder J, Stenstrand K, Fellman J, Herva R, Saarni M, Anttolainen I, Tallila I, Tervila L, Husa L, Tallqvist G, Robson EB, Cook PJL, Sanger R (1974): Pericentric inversions of human chromosome 9 and 10. Am J Hum Genet 26: 746-766

Sakagami K, Yoshida A, Tateno K, Kamiguchi Y, Mikamo K (1988): A case of inverted chromosome no. 9 (homozygote). Folia Opthalmol Jpn 39: 348-353

Sudha T, Gopinath PM (1991): Polymorphism of chromosome 9 and fetal loss. Indian J Obstet Gynecol 41: 21-24

Tibiletti MG, Simoni G, Terzoli GL, Romitti L, Fedele L, Candiani GB (1981): Pericentric inversion of chromosome 9 in couples with repeated spontaneous abortion. Acta Eur Fertil 12: 245-248

Vine DT, Yarkoni S, Cohen MM (1976): Inversion homozygosity of chromosome no. 9 in a highly inbred kindred. Am J Hum Genet 28: 203-207

Wahrman J, Atidia J, Goitein R, Cohen T (1972): Pericentric inversions of chromosome 9 in two families. Cytogenetics 11: 132-144 